\title{
Arsine Poisoning: Massive Haemolysis with Minimal Impairment of Renal Function
}

\author{
G. C. JENKINS,* M.B., PH.D., M.C.PATH ; J. E. IND,† M.B., B.S. ; \\ G. KAZANTZIS, $\ddagger$ M.B., PH.D., F.R.C.S., M.R.C.P. ; R. OWEN,§ M.B., CH.B., D.I.H., D.M.J., L.R.I.C.
}

Brit. med. F., 1965, 2, 78-80

Poisoning by arsine (arseniuretted hydrogen) has become much less common in recent years but still occurs as a hazard of industry. In most instances the gas is evolved as a result of nascent hydrogen being generated in the presence of arsenic, or by the action of water on a metallic arsenide. Clinical manifestations of intoxication usually appear within a few hours of exposure, and include malaise, nausea, vomiting, abdominal pain, and backache, followed by haemolytic anaemia, haemoglobinuria, and pigmentation of the skin. Severe poisoning has most often resulted in death from anuria. The case described here occurred in a metal refinery; haemolysis was severe but renal function was well preserved.

\section{Case Report}

A 19-year-old chemical engineer was referred to the hospital by his general practitioner because of "complete haematuria." A fresh sample of his urine looked like dark blood, but microscopy revealed that it contained no intact red cells.

He had been well until 2 p.m. on the day before admission, when he had an upset stomach with "painful rumblings," nausea, and giddiness. He went home to bed ; five hours later and again twice during the night he passed a normal amount of urine which he thought was "all blood." He vomited twice during the night and again after his admission to hospital. On attempting to get out of bed he collapsed.

On initial examination the patient was deeply bronzed and seemed fairly well, though his temperature was noted to be $100^{\circ} \mathrm{F}$. $\left(37.8^{\circ}\right.$ C.). His mucous membranes were a good colour. The sclerae were a diffuse pink but were definitely not icteric. The iris of each eye was noted to be pale grey in colour, a feature he observed himself soon after admission; it surprised him considerably because they were usually deep brown. The pulse was normal and the bloodpressure 120/70, without any abnormality of the cardiovascular system. Examination of the abdomen revealed no abnormality at this stage other than a slightly tender ascending colon. There was no neurological abnormality.

Occupational History.-The patient was engaged on the separation of metals from scrap, and for the previous eight months he had been working on the recovery of cadmium. The onset of his illness coincided with the trial of a new process which involved reclaiming the metal from flue dust obtained from blast furnaces. The liquor obtained by washing the flue dust with water was acidified with commercial sulphuric acid, heated with steam, stirred, and treated with powdered zinc, which led to the evolution of hydrogen and the separation of cadmium as a sponge. Unfortunately the liquor was contaminated with arsenic from the crude material, and in the presence of nascent hydrogen a large volume of arsine was produced. $\mathrm{He}$ performed this operation for the first time about three hours before he began to feel ill. At the time he noticed nothing more than a dry, bitter taste in his mouth which was not unusual for him at work.

* Consultant Haematologist, North Middlesex Hospital, London. Present address: The London Hospital.

† House-physician, North Middlesex Hospital, London. Present address: Department of Clinical Pathology, St. Bartholomew's Hospital, London.

‡ Air Pollution Research Unit (Medical Research Council), St. Bartholomew's Hospital Medical College, London.

$\S$ H.M. Medical Inspector of Factories.
Investigations.- On his admission the haemoglobin concentration was 10.7 g. $/ 100 \mathrm{ml}$. (73\%), the reticulocyte count $3.8 \%$, and the $\vec{\circ}$ total white-cell count $19,500 / \mathrm{c} . \mathrm{mm}$., of which $81 \%$ were neutro- ? phils. The blood film was normal except for the leucocytosis. The $\overrightarrow{\vec{\omega}}$ direct antiglobulin (Coombs) test was negative. Ham's acid serum test for paroxysmal nocturnal haemoglobinuria, the Donath- $\frac{\sigma}{7}$ Landsteiner test, and the Wassermann and Kahn reactions were all $\underline{3}$. negative. Spectroscopic examination of the plasma revealed $N$ methaemalbumin and an appreciable amount of methaemoglobin or as well as oxyhaemoglobin. The urine obtained prior to admission of was acid in reaction and contained a considerable quantity of protein. The haemoglobin concentration was estimated to be $2.95 \mathrm{~g} . / 100 \mathrm{ml}$. $\infty$

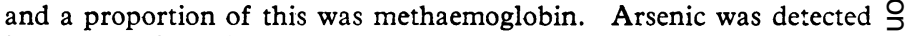
in the sample and was estimated to be present in a concentration of $160 \mu \mathrm{g} . / 100 \mathrm{ml}$. Microscopically there were no casts or red cells and there was no haemosiderin present.

During the two days following his admission the patient became much more ill. He was more anaemic, the skin became more $\vec{\bullet}$ pigmented, and the liver became tender but not palpable. The $\mathrm{G}$ haemoglobin concentration fell to $7.9 \mathrm{~g} . / 100 \mathrm{ml}$. (54\%) (Table I), and at this time it was estimated that the concentration of free haemoglobin in the plasma was $2 \mathrm{~g} . / 100 \mathrm{ml}$. The morphology of the red cells was still normal in the stained blood film. His output of urine remained satisfactory (Table II), so that the haemoglobin level was restored partially by blood transfusions. He was givin dimercaprol (B.P.) $4 \mathrm{ml}$. intramuscularly three times on the third $\overrightarrow{\vec{P}}$ day after admission, and $2 \mathrm{ml}$. daily for the next four days.

\begin{tabular}{|c|c|c|c|c|c|c|c|}
\hline Days after exposure: & $\stackrel{1}{\text { (Admitted) }}$ & 3 & 4 & 5 & 7 & 9 & 15 \\
\hline $\begin{array}{l}\text { Haemoglobin (g./100 ml.) } \\
\text { Reticulocytes }(\%) \\
\text { Blood urea }(\mathrm{mg} . / 100 \mathrm{mi} .) \\
\text { Serum bilirubin }(\mathrm{mg} . / 100 \mathrm{ml} .)\end{array}$ & $\begin{array}{r}10 \cdot 7 \\
3 \cdot 8\end{array}$ & $7 \cdot 9$ & $\begin{array}{l}8 \cdot 0 \\
4 \cdot 4 \\
78 \\
1 \cdot 2 \\
\uparrow \uparrow\end{array}$ & $\begin{array}{r}8.5 \\
64\end{array}$ & $\begin{array}{l}8 \cdot 9 \\
46 \\
1 \cdot 0\end{array}$ & 9.8 & $\begin{array}{r}11 \cdot 1 \\
6 \cdot 0 \\
0 \cdot 6\end{array}$ \\
\hline
\end{tabular}

$\uparrow$ Units transfused blood.

TABLE II.-Urine Values

\begin{tabular}{|c|c|c|c|}
\hline $\begin{array}{c}\text { Days } \\
\text { After } \\
\text { Exposure }\end{array}$ & $\begin{array}{l}\text { Volume } \\
\text { (1./day) }\end{array}$ & $\begin{array}{c}\mathrm{Hb} \\
\text { Concentration } \\
\text { (mg./100 ml.) }\end{array}$ & $\begin{array}{c}\text { Arsenic } \\
\text { Concentration } \\
(\mu \mathrm{g} . / 100 \mathrm{ml} .)\end{array}$ \\
\hline $\begin{array}{r}1 \\
2 \\
3 \\
4 \\
5 \\
6 \\
7 \\
8 \\
9 \\
10 \\
11\end{array}$ & $\begin{array}{l}* \\
* \\
2 \cdot 4 \\
2.9 \\
2 \cdot 7 \\
1.5 \\
3.5 \\
2 \cdot 8 \\
3.3 \\
2 \cdot 8 \\
1.1\end{array}$ & $\begin{array}{c}2,950 \\
400 \\
350 \\
3 \\
2 \\
\mathrm{Nil} \\
\mathrm{Nil} \\
\mathrm{Nil} \\
\mathrm{Nil} \\
\mathrm{Nil} \\
\mathrm{Nil}\end{array}$ & $\begin{array}{c}160 \\
40 \\
15-20 \\
15-20 \\
15-20 \\
15-20 \\
15-20 \\
\mathrm{Nil} \\
\mathrm{Nil} \\
\mathrm{Nil} \\
\mathrm{Nil}\end{array}$ \\
\hline
\end{tabular}

* The volume on these days appeared to be normal.

Three days after admission his urine became almost free from $\stackrel{\mathbb{Q}}{\mathbb{Q}}$ haemoglobin but it contained urobilinogen. At this time the blood urea concentration reached its highest observed level of $78 \mathrm{mg} . /$ $100 \mathrm{ml}$. The plasma potassium was then $4 \mathrm{mEq} / 1$., with sodium? $141 \mathrm{mEq} / \mathrm{l}$. and bicarbonate $22 \mathrm{mEq} / \mathrm{l}$. Haemoglobin disappeared from the plasma by the sixth day of his stay in hospital and heô
began to improve clinically with loss of hepatic tenderness.

At no time was the serum bilirubin found to rise above $1.2 \mathrm{mg}$./ $100 \mathrm{ml}$. Thymol and zinc sulphate turbidity tests and serum alkaline phosphatase estimations were all normal. Both serum transaminase

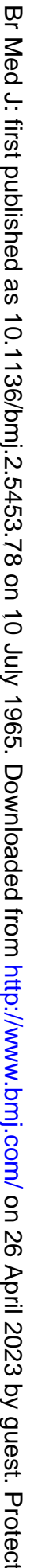


levels were near the upper limit of normal on two occasions, though the serum lactate dehydrogenase rose to over 2,000 B.B. units (normal value up to 500 units) on the fourth day after admission. Erythropoietic response to the haemolytic challenge was not brisk as judged by the reticulocyte count and the degree of marrow proliferation. However, the haemoglobin concentration continued to rise slowly, and he was discharged fit 18 days after admission.

In the out-patient clinic one month later he was quite normal and the irises of his eyes were observed to be deep brown in colour.

\section{Discussion}

Buchanan (1962) has reviewed the wide variety of industrial processes and circumstances which have given rise to the evolution of arsine. It is formed when arsenical compounds are reduced by nascent hydrogen, which is in most cases generated by the action of acid on metal, and less often by the action of alkalis on light metals. The arsenic is usually present as a contaminant of the acid or of the metal. Arsine is also formed by the hydrolysis of a metallic arsenide, which can occur when a metallic dross containing arsenic comes into contact with water. Cases of poisoning, some of them fatal, have followed the accidental wetting of such waste material. Arsine poisoning is a particularly dangerous industrial hazard because its occurrence may be entirely fortuitous and unsuspected, and a fatal dose may be inhaled before the danger is apparent. In the present case the processors were not aware of the arsenic contained in the dust washings, which were subjected to acid and zinc treatment. The arsenic concentration in this liquor was subsequently estimated to be $350 \mathrm{mg}$./litre. Buchanan (1962) quotes a mortality of $22.5 \%$ among the 120 cases reported since 1900 . The important toxic effects are acute haemolytic anaemia and renal and hepatic damage.

\section{Effect on Blood-forming Tissues}

The way in which arsine destroys red cells is still not understood. Arsine produces haemolysis of red cells in vitro only in the presence of oxygen (Naunyn, 1868), although its stable oxidation products, arsenic trioxide and arsenic pentoxide, are not lytic (Kensler, Abels, and Rhoads, 1946). Labes (1937) suggested that arsine in the red cells oxidized to colloidal elementary arsenic, which was the haemolytic agent. Heubner and Wolff (1936) thought that the destructive agent was arsenic dihydride, which is an intermediate product in the oxidation of arsine to arsenious oxide. Using arsine-poisoned rabbits, Graham, Crawford, and Marrian (1946) showed that the arsenic of the red-cell haemolysate was in both dialysable and nondialysable forms, of which the former behaved as an arsenite.

Leucocytosis appears to be a constant feature of cases of severe arsine poisoning and is presumably due to the acute haemolytic episode (Dacie, 1962).

It is worthy of note that the morphology of the red cells in our case was normal even at the time when haemolysis was very severe, and no cell fragmentation was apparent in the blood film. The slow erythropoietic response to this severe haemolytic process might be attributed to the direct depression of marrow activity by arsenic, though it is surprising that leucopoiesis was not similarly affected.

\section{Effect on Kidney}

Renal failure appears to be the lethal factor in most cases that prove to be fatal. An explanation usually offered is that haemoglobin crystals obstruct the renal tubules, with resulting suppression of urine. In our case, despite the rapid destruction of about half of the total volume of red cells, urinary output remained very good. In their comprehensive survey of this condition, Locket, Grieve, and Phillips (1952) pointed out that in their fatal case anuria occurred immediately atter exposure but that the haemoglobin concentration of the blood was still $9.86 \mathrm{~g} . / 100 \mathrm{ml}$. some eight hours later. Their histological report described severe damage to the kidney tubules. They stated that the anuria was probably anoxaemic in origin and emphasized that administration of oxygen was a rational therapeutic measure. Levvy (1947) expressed a view which supports this argument; as a result of his experiments with mice he reasoned that an appreciable fraction of the arsine inhaled is dissolved in the plasma before it becomes attached to red cells and it may exert a toxic action on the tissues before fixation. Arsen:c acts in vivo by having a marked affinity for - $\mathrm{SH}$ groups, and it is reasonable to believe that many of the arsenic compounds attack the $-\mathrm{SH}$ groups of a respiratory enzyme.

Mollison (1962) quotes several experimental observations in which large volumes of haemoglobin have been introduced into the circulation with little or no effect on the renal output. It was suggested by Yuile, Van Zandt, Ervin, and Young (1949) that, even with severe haemoglobinuria, oliguria occurs only if the k'dneys have been subjected to damage by shock, ischaemia, chemical poison, etc. In the present case it may be postulated that the kidneys were only slightly affected by the poison and were able to cope with the intense haemoglobinuria; although there was a fairly constant diuresis, indicating the possibility of mild tubular damage.

The question arises whether dimercaprol may have exerted a protective action on the kidney in our patient. In a case reported by Kipling and Fothergill (1964) severe haemolysis occurred with little renal involvement, and this was followed by recovery without giving dimercaprol. Extensive experimental work by Kensler et al. (1964) showed that dimercaprol had little protective value against the effects of arsine and was certainly not effective when given more than a few hours after exposure.

\section{Effect on Liver}

In the case here described there was evidence of only slight liver dysfunction, although there was severe red-cell destruction. It seems likely that the excessively high lactate dehydrogenase level was due to release of this enzyme from the destroyed erythrocytes.

Much of the literature describes the skin pigmentation in this condition as "toxic jaundice," but in most cases it is a much more coppery colour and is usually gone by the third day. Previous authors (Pinto, Petronella, Johns, and Arnold, 1950; Macaulay and Stanley, 1956) have described cases, including fatal ones, which were deeply pigmented but in which the serum bilirubin did not reach high levels. Locket et al. (1952) emphasized that in their case the liver histology was normal post mortem and quoted Maljean (1900), who said, "The colour of these patients resembles jaundice only at first sight." Certainly the deep pigmentation in our case could not be attributed to bil rubin, but was presumably due to methaemalbumin, methaemoglobin, and related pigments.

The alteration in pigmentation of the eye deserves further comment. No previous record can be found of such a change in similar cases of poisoning by arsine; it is possible that a relatively insignificant and transient ocular feature would remain unnoticed in the midst of other factors which threaten life. The cause of it is obscure, but it would appear that chemical interference with the production of melanin, possibly by affecting the enzymatic activity of tyrosinase, resulted in a deficiency of pigment in the iris. The observation may be of diagnostic value, and further studies on this aspect will be pursued.

\section{Summary}

A case of arsine poisoning is described which was followed by recovery. Red-cell destruction was severe, but the resulting 
haemoglobinuria did not seriously affect renal function. Marked pigmentation of the skin occurred, but liver function was relatively little affected. A transient decolorization of the irides was observed to accompany the intoxication.

We would like to thank Dr. W. G. Dangerfield for much helpful advice and Dr. D. G. Ferriman, under whose care the patient was admitted.

\section{REFERENCES}

Buchanan, W. D. (1962). Toxicity of Arsenic Compounds. Elsevier, Amsterdam.

Dacie, J. V. (1962). The Haemolytic Anaemias, 2nd ed., part. 2, p. 360. Churchill, London.
Graham, A. F., Crawford, T. B. B., and Marrian, G. F. (1946). Biochem.

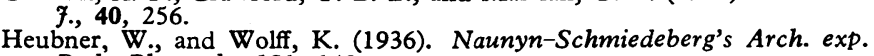
Path. Pharmak., 181, 149.

Kensler, C. J., Abels, J. C., and Rhoads, C. P. (1946). F. Pbarmacol. exp. Ther., 88, 99.

Kipling, M. D., and Fothergill, R. (1964). Brit. f. industr. Med., 21, 74. Labes, R. (1937). Kolloidzschr., 79, 1.

Levvy, G. A. (1947). Quart. F. exp. Physiol., 34, 47.

Locket, S., Grieve, W. S. M., and Phillips, L. (1952). Trans. Ass. industr., med. Offrs, 2, 14.

Macaulay, D. B., and Stanley, D. A. (1956). Brit. F. industr. Med., 13, 217.

Mal;ean (1900). Arch. Méd. Pharm. milit., 35, 82.

Mollison, P. L. (1961). Blood Transfusion in Clinical Medicine, 3rd ed., p. 500. Blackwell, Oxford.

Naunyn, B. (1868). Arch. Anat. Physiol. (Lpz.), p. 401.

Pinto, S. S., Petronella, S. J., Johns, D. R., and Arnold, M. F. (1950). Arch. industr. Hyg., $1,437$.

Yuile, C. L., Van Zandt, T. F., Ervin, D. M., and Young, L. E. (1949). Blood, 4, 1232.

\title{
Triple Primary $\mathbf{\alpha}_{\mathbf{\alpha}}$ Carcinomata of Rectum, Breast, and Transverse Colon Associated with Dermatomyositis
}

\author{
EDWARD WILSON,* F.R.c.s. ; A. G. FINLEY,† D.D.M. ; MARK KILLINGBACK, ‡ F.R.C.s.
}

Over the years cases of multiple malignancies have been reported from clinical and necropsy material by various authors, including Wooley (1903), Warren and Gates (1932), Warren and Ehrenreich (1944), Bacon (1945), Slaughter (1946), Wynder et al. (1956), Dibble and Chambers (1960), and Werthamer et al. (1961); and a study of these cases shows that they fall into four groups. In the great majority two or more primary tumours have appeared in the same organ, such as the large bowel, the skin, or the mouth. Occasionally, multiple tumours have occurred in paired viscera or in viscera of the same system -for example, the renal pelvis and ureter-and, finally, to a much less extent multiple primary malignant tumours have occurred in unrelated organs, as in the case reported here.

In a comprehensive review of the literature Warren and Gates (1932) collected 37 cases which had been reported with three malignant tumours, but the only reference to a patient with two primary carcinomata of the large bowel and a primary carcinoma of the breast was that of Lane (1909). Since then no similar case has been reported, but cases with triple primary malignancies of the breast, large bowel, and an additional viscus have been recorded by Warren and Ehrenreich (1944), who described triple primary carcinomata in a man of 75 affecting the breast, rectum, and prostate, and by Cahan (1955), who described the case of a woman with triple primary carcinomata of the breast, sigmoid colon, and lung.

In 10 to $20 \%$ of adults suffering from dermatomyositis there is an associated malignant tumour (Williams, 1959), but a review of the literature has not revealed any report of a case associated with multiple primary malignant tumours.

\section{Case Report}

A married woman aged 54 was first seen on 2 January 1963 complaining of red swollen nail-folds which had been present for

\footnotetext{
* Honorary Surgeon, Sydney Hospital, Sydney, New South Wales,

t Honorary Dermatologist, Sydney Hospital, Sydney, New South Wales, Australia.

‡ Honorary Assistant Surgeon, Sydney Hospital, Sydney, New South Wales, Australia.
}

three months. Her occupation entailed much wet work, and the disorder had been regarded as chronic paronychia and treated accordingly. She said she was otherwise well, but specific questioning revealed that she had noticed a mild degree of stiffness in her fingers and intermittent redness and swelling of her eyelids for a period of two months. There had also been a recent episode in which she developed redness on her upper chest after exposure to the sun, and this persisted for much longer than she would normally have expected with sunburn. There was no history of dysphagia or other symptoms suggestive of muscle weakness.

Examination revealed a blue discoloration and slight thickening of the nail-folds. There were also some very small ill-defined blue areas on the dorsa of the hands and below the eyes. There was no evidence of muscle wasting or tenderness. Laboratory investigations revealed a mild neutropenia. Haematocrit estimation was $41.5 \%$ and white blood cell count $5,100 / \mathrm{c}$.mm. (neutrophils $48 \%$, eosinophils $4 \%$, basophils $1 \%$, lymphocytes $44 \%$, monocytes $3 \%$ ). Platelets were plentiful, the E.S.R. was. $7 \mathrm{~mm}$. per hour (Westergren), and the S.G.O.T. 20 units.

A diagnosis of dermatomyositis was made, and the patient was admitted to Sydney Hospital on 14 February. In view of her age the possibility of occult malignancy was considered. Just prior to admission she had developed aching in her back. Further questioning revealed that she had noticed occasional slight bleeding per rectum. Her general physical examination revealed nothing of any note, but the left breast was found to contain a thickening in its upper and outer quadrant. There was dimpling of the overlying skin, but no discrete mass was palpable. In the left axilla two enlarged hard lymph nodes were attached to the deeper structures. No lymph node was palpable in the right axilla or neck.

On proctosigmoidoscopy a typically malignant ulcer was found with its lower edge $15 \mathrm{~cm}$. from the anus. Biopsy of this edge showed "infiltrating adenocarcinoma." Small first-degree haemorrhoids were also present.

At this time she had a leucopenia, her white blood cell count being $3,600 /$ c.mm. (neutrophils $62 \%$, eosinophils $2 \%$, lymphocytes $27 \%$, monocytes $9 \%$ ) ; E.S.R. was $8 \mathrm{~mm}$. per hour, and S.G.O.T. 17 units. Serum proteins, electrophoretogram, serum electrolytes, blood urea, and liver-function tests were within normal limits. $X$ ray examination of the chest showed nothing abnormal.

On 18 March a radical anterior resection of the upper rectum and lower sigmoid colon was performed (E.W.). No intraabdominal metastasis or second colonic tumour was detected during 